\title{
National Survey of the Pharmacokinetics Services at the Ministry of Health Hospitals in Saudi Arabia: Drug Therapy Monitoring and Healthcare Professional Education
}

\author{
Yousef Ahmed Alomi ${ }^{1} *$ (D), Rasha Abdelsalam Elshenawy², Sultan Mohammed Al-Jarallah ${ }^{3}$ \\ ${ }^{1}$ The Former General Manager of General Administration of Pharmaceutical Care, Former Head, National Clinical \\ Pharmacy and Pharmacy Practice, Former Head, Pharmacy R and D Administration, Ministry of Health, Riyadh, \\ SAUDI ARABIA. \\ ${ }^{2}$ General Administration of Pharmaceutical Care, Ministry of Health, Riyadh, SAUDI ARABIA. \\ ${ }^{3}$ Head, Ambulatory Care Pharmacy, Oncology and Hematology Clinical Pharmacist, Pharmacentical Care Department, \\ Security Forces Hospital, Riyadh, SAUDI ARABIA.
}

\begin{abstract}
Objectives: A clinical pharmacist offers vital support in the expansion of a final prescription with improved patient management and enhanced safety. The aim of the current study to explore the Pharmacokinetics services at Ministry of Health $(\mathrm{MOH})$ hospitals in Saudi Arabia with an emphasis on drug therapy monitoring and patient's education. Methods: This is a 2-months cross-sectional national survey related to the Pharmacokinetics services with a focus on drug therapy monitoring and education of pharmacist at $\mathrm{MOH}$ hospitals in Saudi Arabia. The study consisted of two parts; the first part captures demographic information and the second part contained 43 questions designed by the authors. It was derived from American Society of Health-System Pharmacists (ASHP) guidelines and from the literature. We used the 5-point Likert response scale system to obtain responses of the participants; there were close-ended questions. The electronic questionnaire was distributed to all the coordinators of the clinical pharmacy services or to the drug information centers at $\mathrm{MOH}$ hospitals. All analysis was done through survey monkey system. Results: A total of 43 hospital pharmacies returned the survey, for a response rate of $86 \%$. The most clinical pharmacokinetics services documented were drug quality reporting 34 (87.18\%), drug information inquiries 35 (83.33\%), adverse drug reaction 35 (81.40\%) and medication error 35 (81.40\%). Highest clinical impact and cost avoidance of clinical Pharmacokinetics services were drug information inquiries 25 (60.98\%), the drug quality reporting system 21 (53.85\%) and pharmacist intervention 21 (52.5\%). Analysis of monthly workload for clinical Pharmacokinetics services were a number of drug information inquiries 28 (70\%) and the number of prescriptions needs 25 (64.1\%). The clinical Pharmacokinetics services education and training for pharmacists were found at average $7.8(20.89 \%)$ hospitals with high percentages type of educations was short education course $1-5$ days [15 (39.47\%)] and long training course $4-5$ weeks [8 (21.05\%)]. While Pharmacokinetics services education and training for healthcare provider were found at main $6(15.66 \%)$ hospitals only with high percentages type of educations was short education course 1-5 days [8 (20.00\%)] and Pharmacokinetics competencies 7 (18.92\%). Conclusion: Pharmacokinetics services on drug therapy monitoring was not competent at half $\mathrm{MOH}$ hospital, while only few of the hospitals had pharmacokinetics education and training to offer. Implementing the $\mathrm{MOH}$ pharmacokinetics services strategy with an emphasis on the drug therapy monitoring with education and training is required at all $\mathrm{MOH}$ hospitals in Saudi Arabia. Key words: Pharmacokinetics Services, Monitoring, Therapy, Healthcare, Education, Ministry of Health, Saudi Arabia.
\end{abstract}

Received: 17-10-2018;

Accepted: 25-01-2019

*Correspondence to:

Dr. Yousef Ahmed Alomi

The Former General Manager of Genera Administration of Pharmaceutical Care, Former Head, National Clinical Pharmacy and Pharmacy Practice, Former Head, Pharmacy R and D Administration, Ministry of Health, P.O.BOX 100, Riyadh 11392, Riyadh, SAUDI ARABIA.

Phone no: +966504417712

Email: yalomi@gmail.com

DOI: 10.5530/ijpcs.2019.8.17

Copyright: ( ) the author(s),publisher and licensee International Journal of Pharmacology and Clinical Sciences. This is an open-access article distributed under the terms of the Creative Commons Attribution Non-Commercial License, which permits unrestricted noncommercial use, distribution, and reproduction in any medium, provided the original work is properly cited.

This is an open access article distributed under the terms of the Creative Commons Attribution-NonCommercial-ShareAlike 4.0 License

Access this article online

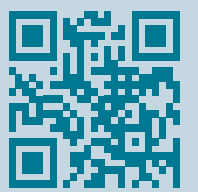

www.ijpcs.net 


\section{INTRODUCTION}

Clinical Pharmacokinetic (PK) calculations are a key competencies for the pharmacists, which is important to ensure the safe use of drugs. ${ }^{[1]}$ Clinical pharmacists with specialized education, training or experience play an essential role in the improvement of the clinical outcome of the patient and to approve responsibilities such as designing and conducting research to increase clinical pharmacokinetic information. Evaluation and expansion of clinical pharmacokinetic monitoring was an integral part of pharmaceutical care. In addition to developing and applying computer programs and pointof-care information systems to enhance the accuracy and sophistication of pharmacokinetic modeling, applications to pharmaceutical care and serving as an expert consultant to pharmacists with a general background in clinical pharmacokinetic monitoring. ${ }^{[2]}$

Few studies investigated the pharmacokinetics services survey over hospitals. It included general pharmacokinetic practice, medication monitored, cost avoidance and perception toward of the services. ${ }^{[3-7]}$ Monitoring of drug therapy including workload analysis of pharmacokinetics and documentation does not occur in most of the literature. Also, the pharmacokinetics education and training were not included in most of the published survey in the worldwide and Gulf or Middle East countries. The objective of this study is to explore the Pharmacokinetics services at Ministry of Health $(\mathrm{MOH})$ hospitals in Saudi Arabia with an emphasis on pharmacokinetics workload, documentation, healthcare provider education and training.

\section{METHODS}

This is a 2-months cross-sectional national survey related to the Pharmacokinetics services with a focus on drug therapy monitoring and education of pharmacist and healthcare providers at MOH hospitals in Saudi Arabia. This study consists of two parts: the first part captures demographic information and the second part is a questionnaire with 43 questions divided into four domains that are derived from the guidelines of the of the American Society of Health-System Pharmacists (ASHP) and from the literature. ${ }^{[3-6]}$ The domains were belonging to the pharmacy management and resources, medication prescribing and dispensing, drug monitoring and healthcare education and perceptions and barrier of services implementations. The 5-point Likert response scale system was used with closed and ended questions. An electronic questionnaire was distributed to the coordinator of all the clinical pharmacy services or drug information centers at $\mathrm{MOH}$ hospitals. All analysis is done through survey monkey system with emphasis on drug monitoring and healthcare education.

\section{RESULTS}

A total of 43 hospital pharmacies returned the survey, for a response rate of $86 \%$. Most of the hospitals responded were with $200-299$ beds [14 (32.6\%)] and with 100-199 beds [10 (23.3\%)]. Most of the hospitals had accreditation from the Saudi Central Board for Accreditation of Healthcare Institutions (CBAHI) [17 (39.53\%)] and from the Joint Commotion USA [11 (25.59\%)]; however, 8 (16.6\%) hospitals did not have any accreditations (Table 1). The highest level of education of the responders was found to be Bachelor of Pharmacy [22 (51.2\%)], Master of Science [12 (27.91\%)] and Doctor of Pharmacy [11 (25.58\%)]. Most of the responders were with greater than or equal to 6 and 1-3 years of experience in the field of pharmacokinetics services [9 (20.9\%)]. None of the responders had Board of Pharmaceutical Specialties (Table 2).

The most clinical Pharmacokinetics services were drug quality reporting 34 (87.18\%), drug information inquiries $35(83.33 \%)$, adverse drug reaction

\begin{tabular}{|c|c|c|}
\hline Number of beds & $\begin{array}{l}\text { Response } \\
\text { Count }\end{array}$ & Response Percent \\
\hline$<50$ & 3 & $7.0 \%$ \\
\hline $50-99$ & 6 & $14.0 \%$ \\
\hline 100-199 & 10 & $23.3 \%$ \\
\hline 200-299 & 14 & $32.6 \%$ \\
\hline 300-399 & 6 & $14.0 \%$ \\
\hline $400-499$ & 4 & $9.3 \%$ \\
\hline 500-599 & 0 & $0.0 \%$ \\
\hline$=$ or $>600$ & 0 & $0.0 \%$ \\
\hline Medical City & 3 & $7.0 \%$ \\
\hline Answered question & 43 & \\
\hline Skipped question & 0 & \\
\hline $\begin{array}{l}\text { The hospital } \\
\text { accreditation }\end{array}$ & $\begin{array}{l}\text { Response } \\
\text { Count }\end{array}$ & Response Percent \\
\hline CBAHI & 17 & $39.53 \%$ \\
\hline Joint Commotion USA & 11 & $25.58 \%$ \\
\hline Canada & 0 & $0.00 \%$ \\
\hline $\begin{array}{l}\text { Saudi commission of health } \\
\text { accreditation }\end{array}$ & 7 & $16.28 \%$ \\
\hline Non & 8 & $18.60 \%$ \\
\hline Answered question & 43 & \\
\hline Skipped question & 0 & \\
\hline
\end{tabular}




\begin{tabular}{|c|c|c|}
\hline Academic Qualification (s) & Response Count & Response Percent \\
\hline Diploma. Pharmacy & 4 & $9.30 \%$ \\
\hline B.Sc. Pharmacy & 22 & $51.16 \%$ \\
\hline Master of Science & 12 & $27.91 \%$ \\
\hline Doctor of Pharmacy & 11 & $25.58 \%$ \\
\hline Two years Residency (R1) & 1 & $2.33 \%$ \\
\hline Three years Residency (R2) & 0 & $0.00 \%$ \\
\hline Ph. D & 1 & $2.33 \%$ \\
\hline M.B.A. & 1 & $2.33 \%$ \\
\hline Answered question & 43 & \\
\hline Skipped question & 0 & \\
\hline Board of Pharmaceutical Specialty & Response Count & Response Percent \\
\hline Board Certified Ambulatory Care Pharmacist (BCACP) & 0 & $0.0 \%$ \\
\hline Board Certified Critical Care Pharmacist (BCCCP) & 0 & $0.0 \%$ \\
\hline Board Certified Nuclear Pharmacist (BCNP) & 0 & $0.0 \%$ \\
\hline Board Certified Nutrition Support Pharmacist (BCNSP) & 0 & $0.0 \%$ \\
\hline Board Certified Oncology Pharmacist (BCOP) & 0 & $0.0 \%$ \\
\hline Board Certified Pediatric Pharmacy Specialist (BCPPS) & 0 & $0.0 \%$ \\
\hline Board Certified Pharmacotherapy Specialists (BCPS) & 0 & $0.0 \%$ \\
\hline Board Certified Psychiatric Pharmacist (BCPP) & 0 & $0.0 \%$ \\
\hline Non & 38 & $100.0 \%$ \\
\hline Other, please specify & 0 & $0.0 \%$ \\
\hline Answered question & 38 & \\
\hline Skipped question & 5 & \\
\hline Total years of Experiences in Pharmacokinetic services & Response Count & Response Percent \\
\hline$<1$ year & 4 & $9.3 \%$ \\
\hline $1-3$ years & 9 & $20.9 \%$ \\
\hline $4-6$ years & 7 & $16.3 \%$ \\
\hline$=$ or $>6$ years & 9 & $20.9 \%$ \\
\hline No experiences & 11 & $25.6 \%$ \\
\hline Other, please specify & 3 & $7.0 \%$ \\
\hline Answered question & 43 & \\
\hline Skipped question & 0 & \\
\hline
\end{tabular}

$35(81.40 \%)$ and medication error $35(81.40 \%)$. Electronic documentation for clinical Pharmacokinetics services were drug quality reporting 7.8 (20.00\%), drug information inquiries 6 (14.29\%), adverse drug reaction $5.38(12.50 \%)$ and medication error 5.38 (12.50\%). Highest clinical impact and cost avoidance documented of clinical Pharmacokinetics services were drug information inquiries $25(60.98 \%)$, the drug quality reporting system $21(53.85 \%)$ and pharmacist intervention 21 (52.5\%) (Table 3 and 4).

Analysis of monthly workload for clinical Pharmacokinetics services were a number of drug information inquiries $28(70 \%)$, the number of prescriptions needs 25 (64.1\%), the number of patients required $25(62.5 \%)$ and a number of adverse drug reaction 24 (58.54\%) and medication errors 25 (58.14\%)
(Table 5). The clinical Pharmacokinetics services education and training for pharmacists were found at average 7.8 (20.89\%) hospitals with high percentages type of educations was short education course 1-5 days [15 (39.47\%)] and long training course $4-5$ weeks [8 (21.05\%)]. While Pharmacokinetics services education and training for healthcare provider were found at main 6 (15.66\%) hospitals only with high percentages type of educations was short education course 1-5 days [8 (20.00\%)] and Pharmacokinetics competencies 7 (18.92\%) (Table 6).

\section{DISCUSSION}

According to results, the response rate was found to be decent in different geographical areas of KSA. In KSA, we found a significant influence of the pharmacist on 
Alomi, et al.: Pharmacokinetics Services in Saudi Arabia: Drug Therapy Monitoring and Healthcare Education

\begin{tabular}{|l|c|c|c|c|c|c|c|c|}
\hline Table 3: Clinical Pharmacokinetics services in the pharmacy. \\
\hline $\begin{array}{l}\text { Answer } \\
\text { Options }\end{array}$ & $\begin{array}{l}\text { Yes } \\
\text { manually }\end{array}$ & $\begin{array}{l}\text { Yes } \\
\text { electronically }\end{array}$ & No. & $\begin{array}{l}\text { No. of } \\
\text { existed } \\
\text { manually }\end{array}$ & $\begin{array}{l}\text { Percent } \\
\text { of existed } \\
\text { manually }\end{array}$ & $\begin{array}{l}\text { No. of existed } \\
\text { electronically }\end{array}$ & $\begin{array}{l}\text { Percent } \\
\text { of existed } \\
\text { manually }\end{array}$ & $\begin{array}{l}\text { Response } \\
\text { Count }\end{array}$ \\
\hline Medication errors & 29 & 7 & 8 & 35 & $81.40 \%$ & 5.38 & $12.50 \%$ & 43 \\
\hline $\begin{array}{l}\text { Adverse drug } \\
\text { reactions }\end{array}$ & 30 & 8 & 8 & 35 & $81.40 \%$ & 5.38 & $12.50 \%$ & 43 \\
\hline $\begin{array}{l}\text { Drug quality } \\
\text { reporting }\end{array}$ & 29 & 10 & 5 & 34 & $87.18 \%$ & 7.80 & $20.00 \%$ & 39 \\
\hline Patient counseling & 25 & 5 & 14 & 27 & $65.85 \%$ & 2.93 & $7.14 \%$ & 41 \\
\hline $\begin{array}{l}\text { Pharmacist } \\
\text { intervention }\end{array}$ & 24 & 8 & 11 & 32 & $74.42 \%$ & 3.91 & $9.09 \%$ & 43 \\
\hline $\begin{array}{l}\text { Drug information } \\
\text { inquiries }\end{array}$ & 27 & 13 & 7 & 35 & $83.33 \%$ & 6.00 & $14.29 \%$ & 42 \\
\hline $\begin{array}{l}\text { Poisoning } \\
\text { information } \\
\text { inquiries }\end{array}$ & 22 & 5 & 16 & 25 & $60.98 \%$ & 2.56 & $6.25 \%$ & 41 \\
\hline Answered Question & & & & & & & & 43 \\
\hline Skipped Question
\end{tabular}

\section{Table 4: Clinical impact and cost avoidance of clinical Pharmacokinetics services.}

\begin{tabular}{|c|c|c|c|c|c|c|c|}
\hline Answer Options & Adults & Pediatrics & Neonates & $\begin{array}{l}\text { We do not } \\
\text { have it }\end{array}$ & $\begin{array}{l}\text { No. of } \\
\text { existed }\end{array}$ & $\begin{array}{l}\text { Percent of } \\
\text { existed }\end{array}$ & $\begin{array}{l}\text { Response } \\
\text { Count }\end{array}$ \\
\hline Medication errors & 19 & 10 & 7 & 23 & 20 & $46.51 \%$ & 43 \\
\hline Adverse drug reactions & 21 & 14 & 10 & 20 & 22 & $52.38 \%$ & 42 \\
\hline Drug quality reporting & 20 & 9 & 5 & 18 & 21 & $53.85 \%$ & 39 \\
\hline Patient counseling & 18 & 7 & 5 & 21 & 19 & $47.50 \%$ & 40 \\
\hline Pharmacist intervention & 20 & 12 & 11 & 19 & 21 & $52.50 \%$ & 40 \\
\hline Drug information inquiries & 23 & 15 & 8 & 16 & 25 & $60.98 \%$ & 41 \\
\hline Poisoning information inquiries & 19 & 10 & 6 & 20 & 19 & $48.72 \%$ & 39 \\
\hline \multicolumn{5}{|l|}{ Answered Question } & & & 43 \\
\hline \multicolumn{5}{|l|}{ Skipped Question } & & & 0 \\
\hline
\end{tabular}

\begin{tabular}{|c|c|c|c|c|c|c|c|}
\hline Answer Options & Adults & Pediatrics & Neonates & Never & $\begin{array}{l}\text { No. of } \\
\text { existed }\end{array}$ & $\begin{array}{l}\text { Percent of } \\
\text { existed }\end{array}$ & $\begin{array}{l}\text { Response } \\
\text { Count }\end{array}$ \\
\hline No. of Medication errors & 25 & 13 & 4 & 18 & 25 & $58.14 \%$ & 43 \\
\hline No. of Adverse drug reactions & 22 & 15 & 6 & 17 & 24 & $58.54 \%$ & 41 \\
\hline No. of Drug quality reporting & 18 & 10 & 5 & 19 & 20 & $51.28 \%$ & 39 \\
\hline No. of Patient counseling & 15 & 8 & 3 & 22 & 17 & $43.59 \%$ & 39 \\
\hline No. of Pharmacist intervention & 19 & 11 & 6 & 18 & 23 & $56.10 \%$ & 41 \\
\hline No. of Drug information inquiries & 26 & 14 & 10 & 12 & 28 & $70.00 \%$ & 40 \\
\hline No. of Poisoning information inquiries & 16 & 10 & 4 & 18 & 18 & $50.00 \%$ & 36 \\
\hline No. of patients & 24 & 15 & 11 & 15 & 25 & $62.50 \%$ & 40 \\
\hline No. of prescriptions & 24 & 13 & 7 & 14 & 25 & $64.10 \%$ & 39 \\
\hline Clinical outcomes impact & 12 & 6 & 5 & 22 & 13 & $37.14 \%$ & 35 \\
\hline Total No. of drug level & 9 & 9 & 4 & 24 & 12 & $33.33 \%$ & 36 \\
\hline Total No. of drug level above of range & 11 & 9 & 4 & 25 & 12 & $32.43 \%$ & 37 \\
\hline Total No. of drug level below of range & 10 & 9 & 4 & 24 & 13 & $35.14 \%$ & 37 \\
\hline Total No. of sampling time & 9 & 7 & 3 & 25 & 11 & $30.56 \%$ & 36 \\
\hline Total No. of wrong sampling time & 7 & 6 & 2 & 27 & 9 & $25.00 \%$ & 36 \\
\hline Cost avoidance impact & 6 & 4 & 0 & 28 & 8 & $22.22 \%$ & 36 \\
\hline \multicolumn{5}{|l|}{ Answered Question } & & & 43 \\
\hline \multicolumn{5}{|l|}{ Skipped Question } & & & 0 \\
\hline
\end{tabular}


Alomi, et al.: Pharmacokinetics Services in Saudi Arabia: Drug Therapy Monitoring and Healthcare Education

\begin{tabular}{|c|c|c|c|c|c|c|c|c|}
\hline $\begin{array}{l}\text { Answer } \\
\text { Options }\end{array}$ & $\begin{array}{l}\text { Pharmacy } \\
\text { technician }\end{array}$ & Pharmacist & $\begin{array}{l}\text { Clinical } \\
\text { Pharmacist }\end{array}$ & $\begin{array}{l}\text { Emergency } \\
\text { Pharmacy } \\
\text { supervisor }\end{array}$ & $\begin{array}{l}\text { We do } \\
\text { not } \\
\text { have it }\end{array}$ & $\begin{array}{l}\text { No. of } \\
\text { existed }\end{array}$ & $\begin{array}{l}\text { Percent } \\
\text { of } \\
\text { existed }\end{array}$ & $\begin{array}{l}\text { Response } \\
\text { Count }\end{array}$ \\
\hline $\begin{array}{l}\text { Short education } \\
\text { course } 1-5 \text { days }\end{array}$ & 6 & 13 & 6 & 1 & 23 & 15 & $39.47 \%$ & 38 \\
\hline $\begin{array}{l}\text { Long training course } \\
4-5 \text { weeks }\end{array}$ & 4 & 6 & 5 & 1 & 30 & 8 & $21.05 \%$ & 38 \\
\hline $\begin{array}{l}\text { General Pharmacist } \\
\text { residency program }\end{array}$ & 3 & 6 & 4 & 1 & 30 & 7 & $18.92 \%$ & 37 \\
\hline $\begin{array}{l}\text { Specialized } \\
\text { pharmacist } \\
\text { residency program }\end{array}$ & 1 & 3 & 3 & 0 & 32 & 4 & $11.11 \%$ & 36 \\
\hline $\begin{array}{l}\text { Distance learning } \\
\text { pharmacy education }\end{array}$ & 0 & 3 & 4 & 0 & 31 & 5 & $13.89 \%$ & 36 \\
\hline \multicolumn{6}{|l|}{ Answered Question } & & & 43 \\
\hline \multicolumn{6}{|l|}{ Skipped Question } & & & 0 \\
\hline $\begin{array}{l}\text { Answer } \\
\text { Options }\end{array}$ & Nurses & Physicians & $\begin{array}{l}\text { ER } \\
\text { technicians }\end{array}$ & $\begin{array}{l}\text { Other } \\
\text { health care } \\
\text { provider }\end{array}$ & $\begin{array}{l}\text { We do } \\
\text { not } \\
\text { have it }\end{array}$ & $\begin{array}{l}\text { No. of } \\
\text { existed }\end{array}$ & $\begin{array}{l}\text { Percent } \\
\text { of } \\
\text { existed }\end{array}$ & $\begin{array}{l}\text { Response } \\
\text { Count }\end{array}$ \\
\hline $\begin{array}{l}\text { Short education } \\
\text { course } 1-5 \text { days }\end{array}$ & 8 & 6 & 1 & 1 & 32 & 8 & $20.00 \%$ & 40 \\
\hline $\begin{array}{l}\text { Long training course } \\
4-5 \text { weeks }\end{array}$ & 4 & 7 & 4 & 3 & 33 & 6 & $15.38 \%$ & 39 \\
\hline $\begin{array}{l}\text { Pharmacokinetics } \\
\text { competencies }\end{array}$ & 6 & 6 & 1 & 0 & 30 & 7 & $18.92 \%$ & 37 \\
\hline $\begin{array}{l}\text { Distance learning } \\
\text { pharmacokinetics } \\
\text { education }\end{array}$ & 2 & 3 & 0 & 0 & 33 & 3 & $8.33 \%$ & 36 \\
\hline \multicolumn{6}{|l|}{ Answered Question } & & & 43 \\
\hline \multicolumn{6}{|l|}{ Skipped Question } & & & 0 \\
\hline
\end{tabular}

the clinical pharmacokinetics services. In therapeutic drug monitoring, pharmacist had a significant influence on the patient condition and outcome. Twenty-four hospitals started their service and the number of hospitals offering the service significantly increased. Hospitals that have the TDM service are generally with a variable number of hospital beds (200-299 beds and 100-199 beds). The findings from this study, to some extent, are similar to those reported elsewhere in Malaysia. ${ }^{[4]}$ The documentation of clinical activities system started at the Ministry of Health in the 1990s. The memo random from Minister of Health stated that any pharmacist has right to interpret with any physicians if there is any mistakes or error or UN-appropriates of drug therapy. Several types of pharmacist interventions or clinical Pharmacokinetics activities included general pharmacy intervention, drug information inquiries, medications errors, adverse drug reactions documentation, patient counseling, drug quality reporting and medications reconciliation. The author and his colleague participated in a poster session at the American College of Clinical Pharmacy conference about pharmacist documentation of clinical activities with included all related intervention. The author explored the highest pattern of documentation were pharmacokinetics services, drug therapy monitoring, patient education and training similar to the previous studies. ${ }^{[8,9]}$ The results expected because the four activities established for a long time almost before more than 25 years ago at KSA hospitals ${ }^{[10]}$ Similary, the author found the same results of workload analysis with the same items including pharmacokinetics consultations. ${ }^{[11,12]}$ The remaking system needs awareness to encourage the pharmacist to start to document the activities. The pharmacokinetics education and training were poor finding because the compete Pharmacokinetics services not existed at all Ministry of Health Hospitals. The education and training of pharmacokinetics services should increase for pharmacist and healthcare providers. Other an innovative educational way for clinical pharmacists. As clinical pharmacy has the most excellent history of advancing practice through innovation. These innovations helped to mold clinical pharmacy into a patient-centered discipline recognized for its contributions to improving medication therapy outcomes. The presence of appropriate online pharmacokinetics, education, leadership and support, a shift in current professional extended education and training and a commitment to cultivating future innovators, the academic-practice 
partnership can develop new and innovative practice advancements that will improve patient outcomes. ${ }^{[13]}$ Most of the study findings could not compare with other examination because the study may be the first pharmacoepidemiology study in this field related to pharmacokinetics with an emphasis on drug therapy monitoring in addition to the type of patient education and training in pharmacy practice in Saudi Arabia, Gulf or Middle East countries or else world locations.

\section{CONCLUSION}

Drug therapy monitoring during Pharmacokinetics services was not competent at $\mathrm{MOH}$ hospital. Only few of the hospitals had pharmacokinetics education and training to offer. There is the need to increase the number of clinical pharmacists who are specialized in this field with a focus on pharmacokinetics education and training at $\mathrm{MOH}$ hospitals in KSA.

\section{ACKNOWLEDGEMENT}

None.

\section{CONFLICT OF INTEREST}

None.

\section{ABBREVIATIONS}

KSA: Kingdom of Saudi Arabia; MOH: Ministry of Health; PK: Clinical Pharmacokinetic; CPS: Clinical pharmacokinetics services; ASHP: American Society of Health-System Pharmacists; TDM: Therapeutic drug monitoring.

\section{ORCID ID}

Yousef Ahmed Alomi (D), https://orcid.org/0000-00031381-628X

\section{REFERENCES}

1. Dornblaser EK. A needs assessment of pharmacokinetic skills performed on advanced pharmacy practice experiences by student pharmacists. Curr Pharm Teach Learn. 2017;9(1):95-100.

2. Galt KA, Demers RF, Herrier RN. ASHP statement on the pharmacist 's role in clinical pharmacogenomics. Am J Heal-Syst Pharm. 1999;56:291-3.

3. Howard CE, Capers CC, Bess DT, Anderson RJ. Pharmacokinetics services in Department of Veterans Affairs medical centers. Am J Hosp Pharm. 1994;51(13):1672-5.

4. AbRahman AF, Ahmed AHE, Mohamed IMI. A survey of therapeutic drug monitoring services in Malaysia. Saudi Pharm J. 2013;21(1):19-24.

5. Alomi YA, Alghamdi SJ, Alattyh RA, Alshahrani AM, Shorog EM, Alasmary SA, et al. National survey of pharmacy practice at $\mathrm{MOH}$ hospitals 2016: Drug monitoring and patient education. Value Heal. 2017;A36.

6. Pedersen CA, Schneider PJ, Scheckelhoff DJ. ASHP national survey of pharmacy practice in hospital settings: Monitoring and patient education-2015. Am J Heal Pharm. 2016;73(17):1307-30.

7. Kheir N, Awaisu A, Gad H, Elazzazy S, Jibril F, Gajam M. Clinical pharmacokinetics: Perceptions of hospital pharmacists in Qatar about how it was taught and how it is applied. Int J Clin Pharm. 2015;37(6):1180-7.

8. Alomi $\mathrm{Y}$, Bakaerman N. Documentation pattern of clinical pharmacist intervention, Riyadh, Saudi Aarbia. In: ACCP Annual Meeting, October, USA. 2007.

9. Alomi YA, Shorog E, Alshahrani A, Alasmary S, Alenazi H, Almutairi A, et al. National Survey of Pharmacy Practice at $\mathrm{MOH}$ Hospitals in Saudi Arabia 2016-2017: Drug Monitoring and Patients Education. J Pharm Pract Community Med. 2018;4(1s):s17-22.

10. Alomi YA. National Pharmacy Practice Programs at Ministry of Health in Saudi Arabia. J Pharm Pharm Scien. 2015;1(2):17-8.

11. Alomi YA. workload Analysis and Staffing Requirement of Clinical Pharmacy Services at Ministry of Saudi Arabia. Value Heal. 2016;19(7):A466.

12. Alomi YA, Alghamdi SJ, Alattyh RA. National Survey of Pharmacy Practice at MOH Hospitals in Saudi Arabia 2016-2017: Clinical Pharmacy Services. J Pharm Pr Community Med. 2018;4(1):1S-8S.

13. Gubbins PO, Micek ST, Badowski M, Cheng J, Gallagher J, Johnson SG, et al. Innovation in clinical pharmacy practice and opportunities for academic-practice partnership. Pharmacotherapy. 2014;34(5):e45-54.

Cite this article as: Alomi YA, Elshenawy RA, Al-Jarallah SM. National Survey of the Pharmacokinetics Services at the Ministry of Health Hospitals in Saudi Arabia: Drug Therapy Monitoring and Healthcare Professional Education. Int J Pharmacol. Clin. Sci. 2019;8(2):99-104. 